\title{
Indirect effects of ant predation (Hymenoptera: Formicidae) on bilberry Vaccinium myrtillus
}

\author{
OLA ATLEGRIM \\ Department of Animal Ecology, Swedish University of Agricultural Sciences, SE-901 83 Umeå, Sweden; e-mail: \\ Ola.Atlegrim@szooek.slu.se
}

Key words. Top-down, indirect effects, Formicidae, Formica aquilonia, ants, bilberry, Vaccinium myrtillus, insect larvae, herbivory, predation effects

\begin{abstract}
Bilberry (Vaccinium myrtillus L.) is one of the dominant plants of the Fennoscandian boreal coniferous forest and constitutes a major food source for many insect herbivores. A common ant species in these forests is the wood ant Formica (Formica) aquilonia Yarrow, which preys heavily on other invertebrates within its territories. The aim of this study was to investigate whether aquilonia's predation on the insect herbivores may have indirect positive or negative effects on bilberry. Damage to the bilberry, its vegetative growth and reproduction were quantified in order to contrast localities close to $(2 \mathrm{~m})$ and far away from $(50 \mathrm{~m})$ ant nests.

Close to ant nests, herbivore damage to the bilberry was significantly lower and reproductive success, i.e. proportion of flowers succeeding to berries, significantly higher. The results of this study therefore suggest that distance to aquilonia nests, and thus predation from ants, can significantly affect herbivore damage to the bilberry and its reproductive success (supporting the hypothesis of a top down effect in this three-trophic-level system). Vegetative growth, i.e., density and biomass of current year shoots, and reproductive investment, i.e., proportion of current year shoots with flower, of the bilberry was, however, not affected by distance to ant nests, indicating that the bilberry can also compensate for losses due to herbivory.
\end{abstract}

\section{INTRODUCTION}

The importance of trophic interactions in determining population sizes and community structure, and whether the primary control is by resources or predators has been the subject of much debate (Hunter \& Price, 1992; Power, 1992; Strong, 1992; Persson, 1999; Lawton, 2000). According to the bottom-up view by White (1978), i.e. control by resources, the availability of different resources to the plants and the limited availability of nitrogen-rich food for herbivores influence all trophic levels. Often as a defence strategy, reduced nitrogen content in plants limits herbivore populations, while factors like behavioural or physiological adaptations of the herbivore limit the access of predators to the resources (White, 1978). The top-down view (Hairston et al., 1960) argues for the importance of predators as a structuring force through the reduction of herbivore populations. In a three-trophic food chain the predators themselves and the producers are instead limited by resources due to competition (Hairston et al., 1960). Today there is increasing recognition that both mechanisms can occur to different degrees in the same place and time (e.g. Hunter \& Price, 1992; Power, 1992). The direct effect of predation by carnivores can have a strong effect on abundance and structure of prey communities and, in a three-trophic-level food web, can also affect the bottom level through indirect effects (Sih et al., 1985; Schoener \& Spiller, 1996, 1999; Spiller \& Schoener, 1998; Schmitz et al., 2000). Terrestrial ecosystems are often thought to be species rich, with plants which have evolved effective defences, causing the effect of predation and primary production to spread throughout the food web (Polis \& Strong, 1996), and therefore dampening the effect of a top-down force. However, Schmitz et al. (2000) found in their review that in the studies which included three trophic levels, 75\% reported significant indirect effects of carnivore removal on some plant variable.

Through omnivory, a consumer can be effectively subsidised from "nontypical" prey and the consumer populations can then be sustained (or even increased) during "poor" periods, thus promoting a top-down control by the consumer (Polis \& Strong, 1996; Schoener \& Spiller, 1996). Also important is a rapid numerical and functional response to changes in resource abundance (Polis, 1999). A group of organisms that fulfils these requirements is the wood ant group in Scandinavian forests. The direct influence of ants on prey populations is rather well known, while knowledge of their indirect effects on ecosystems is less extensive. Aho et al. (1997), for example, showed that wood ants can have a negative indirect effect on the Eurasian treekreeper (Certhia familiaris L.) due to exploitative competition. However, the indirect effects of wood ant predation on plants in boreal systems have largely been overlooked: the review by Schmitz et al. (2000) reveals only one such study.

Due to their high abundance and predatory feeding habits, ants have a major influence not only on the herbivore community that they prey upon, but sometimes on other parts of the biotic community within their feeding territories. Studies in various ecosystems clearly show that ants can reduce the effects of different herbivores (Skinner \& Whittaker, 1981; Risch \& Carroll, 1982; Fowler \& MacGarvin, 1985; Perfecto \& Sediles, 1992; Mahdi \& Whittaker, 1993; Schimtz et al., 2000). However, in order to reduce the predation risk, herbivores have evolved dif- 
ferent feeding behaviours, e.g. free-living herbivores were reduced more than leaf-tiers (Fowler \& MacGarvin, 1985), likely attributable to the latter's greater crypsis (Atlegrim, 1991).

The dominant wood ant in northern Scandinavian boreal forests, Formica (Formica) aquilonia Yarrow (Hymenoptera: Formicidae) builds large mounds in forests (Savolainen et al., 1989; Punttila, 1996; Karhu \& Neuvonen, 1998) and fulfils the requirements for a consumer with the potential for indirect effects in a threelevel trophic interaction web. There are only a few studies on the direct and indirect effects of $F$. aquilonia. Studies from the mountain region of Scandinavia indicate that their presence is of vital importance for the survival of mountain birches (Betula pubescens ssp. tortuosa). This is especially important during years of outbreak of geometrid moths when ant predation results in "green islands" of undamaged birches surrounding the nests (Laine \& Niemelä, 1980; Karhu \& Neuvonen, 1998). Despite a positive correlation between the density of $F$. aquilonia and a tended aphid (Symydobius oblongus von Heyden), the birch profits from the presence of ants and has a lower mortality (Laine \& Niemelä, 1980; Karhu, 1998; Karhu \& Neuvonen, 1998).

The aim of this study was to investigate the indirect effects of predation by $F$. aquilonia on herbivorous insect larvae feeding on the bilberry (Vaccinium myrtillus L.), a dominant shrub in the field layer of Scandinavian forests. I compared herbivore damage and vegetative and reproductive production of the bilberry at localities close to and far away from nests of $F$. aquilonia. More specifically, the following hypotheses were tested: close to $F$. aquilonia nests, where density of workers is high (1) bilberry will have a higher vegetative production, i.e., the density of current year shoots will be higher, (2) the level of bark damage will be lower, (3) the level of leaf damage will be lower, (4) the biomass of the bilberry's current year shoots will be higher, (5) there will be a larger number of fertile shoots, (6) lower damage on reproductive parts, and finally (7) a greater reproductive success, i.e., a larger proportion of fertile shoots with intact fruits.

\section{MATERIAL AND METHODS}

\section{The study system}

Bilberry is a deciduous dwarf shrub having evergreen stems with an average height of 15-45 cm (Mossberg et al., 1992). It is a clonal plant, dispersing through ramets growing from an underground rhizome (Tolvanen \& Laine, 1997). Bilberry often constitutes more than $40 \%$ of the ground cover in the field layer of Fennoscandian boreal forests (Kalliola, 1973). The aboveground biomass of bilberry amounts to $150-200 \mathrm{~g} / \mathrm{m}^{2}$ and about one fourth is renewed each year (Havas \& Kubin, 1983). Bilberry ramets are hierarchically structured with the lowest level as the tiller growing above ground and the highest as the fertile current year shoots (Tolvanen \& Laine, 1997). The current year shoots are carrying leaves, axilliary flowers and dormant buds for next year growth. Dormant buds on the top part of the shoot, which have been initiated during preceding year, develop into new shoots thereby giving the hierarchical structure (Atlegrim, 1991). The age of the ramet can therefore be determined through the number of hierarchical levels. Flowers are initiated at the base of the current year shoots in beginning of June and develop to berries in the end of August. The seeds inside the berries are dispersed by animals and birds which eat the berries and then excrete the seeds (Atlegrim, 1991).

The dominant invertebrate herbivores feeding on bilberry are butterfly (Lepidoptera) and sawfly (Hymenoptera: Symphyta) larvae (Atlegrim, 1991). The folivores, i.e., species from the lepidopteran families Geometridae, Noctuidae, Lasiocampidae, and sawfly species, contain free-living leaf chewers which crawl around freely and, thus have an exposed feeding behaviour (Atlegrim, 1991). The frugivores, i.e., species from the lepidopteran families Tortricidae and Pyralidae, contain larvae that spin leaves together around the reproductive parts of the bilberry (flower/unripe berry), thus constructing a shelter for and making them less conspicuous during feeding (Atlegrim, 1991). Damages to the bilberry caused by these larvae are easily distinguished from damages caused by vertebrates (e.g., grouses, moose, etc.) and other types of invertebrate herbivores (Atlegrim, 1991).

$F$. aquilonia, is the most common of seven mound-building wood ant species belonging to the Formica rufa-group in Scandinavian boreal forests (Savolainen et al., 1989; Douwes, 1995; Punttila, 1996). They build large nests that can be comparable in age to trees (Donisthorpe, 1927; Oinonen, 1956, 1958; Rosengren, 1981). An important characteristic is their aggression and habit of maintaining large territories (Savolainen et al., 1989). The species is polygynous and sometimes forms secondary nests resulting in multi-nest colonies (Hölldobler \& Wilson, 1990; Punttila, 1996) and polycalic, i.e. nests exchange liquid food, offspring and workers (Punttila, 1996). Workers forage on a variety of invertebrates but the colonies are to a very large extent also dependent on honeydew (Karhu \& Neuvonen, 1998).

\section{Study area}

My study area was situated on the western side of Lake Bäcksjön, $15 \mathrm{~km} \mathrm{NW}$ of Umeå in northern Sweden $\left(64^{\circ} 00^{\prime} \mathrm{N}\right.$, $\left.20^{\circ} 20^{\prime} \mathrm{E}\right)$. The tree composition surrounding the ant mounds ranged from being homogeneous Scots pine (Pinus sylvestris Linnaeus) to a mixture with Norway spruce (Picea abies Linnaeus). Bilberry dominated the field layer with ground cover varying between 30 to $60 \%$. Other shrubs occurring as codominants are lingonberry (Vaccinium vitis-idaea Linnaeus), heather [Calluna vulgaris (Linnaeus) Hull] and crowberry (Empetrum nigrum Linnaeus).

\section{General design}

The study was conducted in late August and September 2000. The feeding territory of a wood ant nest include ca $40 \mathrm{~m}$ around the nest (Laakso \& Setälä, 1998) and nest mounds of $F$. aquilonia may be situated at roughly 40-m intervals (Karhu, 1998) which means that in densely populated ant areas there may be no areas free of ants. The ant nests used in this study was however solitary nests. These nests were chosen so that at a distance of $50 \mathrm{~m}$ from the studied nest no other nest occurred within a distance of at least $70 \mathrm{~m}$. Using this design there will be a very low potential for influence of ants $50 \mathrm{~m}$ from the studied nest. Forty such solitary F. aquilonia were localized in the study area and of these twenty-four were randomly chosen for the current study. At each nest, sampling of bilberry was conducted at two positions: (a) $2 \mathrm{~m}$ from the nest (where ants had a high density and high potential effect) and (b) $50 \mathrm{~m}$ from the nest (very low ant density and low potential effect). The positions for the sampling were chosen as similar as possible with respect to sun exposure, moisture conditions, etc. To control for variation in $F$. aquilonia activity (caused by heterogeneously-spaced food items/sources and the distribution of bilberry), I took two sam- 
ples at each position. These samples consisted of circular plots which were randomly located at each position by throwing out a stick with the back towards the sampling area ( 2 or $50 \mathrm{~m}$ from the nest). The stick was used as centre for the circular sampling plots. Two sizes of circular plots were used. Within a $5 \mathrm{dm}^{2}$ circle the number of current year shoots of the bilberry was counted while all other sampling was done in a $10 \mathrm{dm}^{2}$ circle superimposed on the $5 \mathrm{dm}^{2}$ circle.

\section{Vegetative production of bilberry}

The total number of current-year shoots were counted in 5 $\mathrm{dm}^{2}$ circular plots. In the $10 \mathrm{dm}^{2}$ plot, 50 current-year shoots were randomly selected and picked for weight measures. When an insufficient number of shoots was found within the $10 \mathrm{dm}^{2}$ plot, additional shoots were picked just outside. Shoots were dried for three days at $40^{\circ} \mathrm{C}$ and then weighed. The mean shoot weight for each circular plot was calculated by dividing the dry weight of the collected shoots by the total number of shoots. The mean weight of the shoots in the $10 \mathrm{dm}^{2}$ circular plot in combination with the mean number of shoots in the $5 \mathrm{dm}^{2}$ plots was used to calculate total shoot biomass per $\mathrm{m}^{2}$. The following measures of vegetative bilberry production were obtained: a) number of shoots per $\mathrm{m}^{2}, \mathrm{~b}$ ) mean weight of current year shoots and c) biomass of current year shoots per $\mathrm{m}^{2}$.

\section{Reproduction of bilberry}

The 50 shoots collected in the $10 \mathrm{dm}^{2}$ circular plots were used for different measures of bilberry reproduction. If reproductive, current year shoots are recognizable because the stem is thicker at the base; in profile it forms a triangular shape. Thus, even if the shoot has lost the flower/berry it can easily be classified as reproductive or not. The 50 shoots were inspected and divided into the following categories: a) not reproductive, i.e., lacking the triangular shape at the base, b) reproductive but had lost the reproductive part, i.e., had the triangular shape at the base but was lacking the berry, and c) reproductive with intact berry. From this data two measures of reproduction were obtained. First, the reproductive investment, calculated as the proportion of reproductive shoots, i.e., the sum of current-year shoots which had lost their reproductive part during the season (category b) and current-year shoots which still were reproductive at the sampling occasion (category c) divided by the number of inspected shoots (50 shoots). Secondly, the reproductive success, calculated as the proportion of fertile shoots which still were reproductive at the sampling occasion, i.e., the number of current year shoots with an intact berry (category c) divided by the sum of reproductive current year shoots (category b and c).

\section{Herbivore damage}

Three measures of herbivore damage were obtained. The first two measures of herbivore damage (stem and leaf damage index), were obtained using the 50 collected shoots in $10 \mathrm{dm}^{2}$ circular plots. Stem damage was estimated in four classes: intact stems (scored as 0 ), bark damage (scored as 1), stems cut (shoot bitten off; scored as 2) and both types of injury on the same shoot (scored as 3). Thus, higher scores indicate an increasing level of damage and loss of photosynthetic tissue. The damage index was obtained by adding the stem damage scores together and dividing by the total number of shoots (i.e. 50 shoots). Leaf damage were classified into five classes depending on the degree of leaf area removed: a) intact shoots, b) $<10 \%$, c) $10-49 \%$, d) $50-99 \%$ and e) $100 \%$ leaf area removed. To calculate the leaf damage index, the mid value of each defoliation class (i.e. $0,5,30,75$ and $100 \%$ ) was multiplied by the number of shoots in that class. The value for each defoliation class was then summed and divided by the number of shoots (i.e. 50 shoots), to constitute the leaf damage index.
The third herbivore damage index, reproductive damage, was obtained by dividing the number of shoots which had lost their reproductive parts (category b) by the total number of shoots that were classified as reproductive (category b and c; see reproduction of bilberry above).

\section{Statistical analysis}

For each nest, variables were first calculated for each of the 5 $\mathrm{dm}^{2}$ and $10 \mathrm{dm}^{2}$ circular plots. Thereafter, mean values were calculated for the two circular plots at each distance, constituting the values at $2 \mathrm{~m}$ distance, close to nests with high worker density, and at $50 \mathrm{~m}$ distance, far away from nests with low worker density. Differences between localities close to and far away from the ant nest were tested using the non-parametric MannWhitney U-test for independent samples (Siegel, 1956). This test was used because the samples $50 \mathrm{~m}$ away from the nest is on the border of the ants feeding territories and exact paring with the samples $2 \mathrm{~m}$ from the nest could not be done. A nonparametric test was used because the prerequisites of a parametric test, normality and homogeneity, could not be fulfilled even with transformations.

\section{RESULTS}

There were no significant difference between samples taken close to and far away from the nests with respect to the density of activated current year shoots $(\mathrm{z}=1.12, \mathrm{p}=$ $\left.0.1314, \mathrm{n}_{1}=16, \mathrm{n}_{2}=24\right)$, the mean weight of the bil-
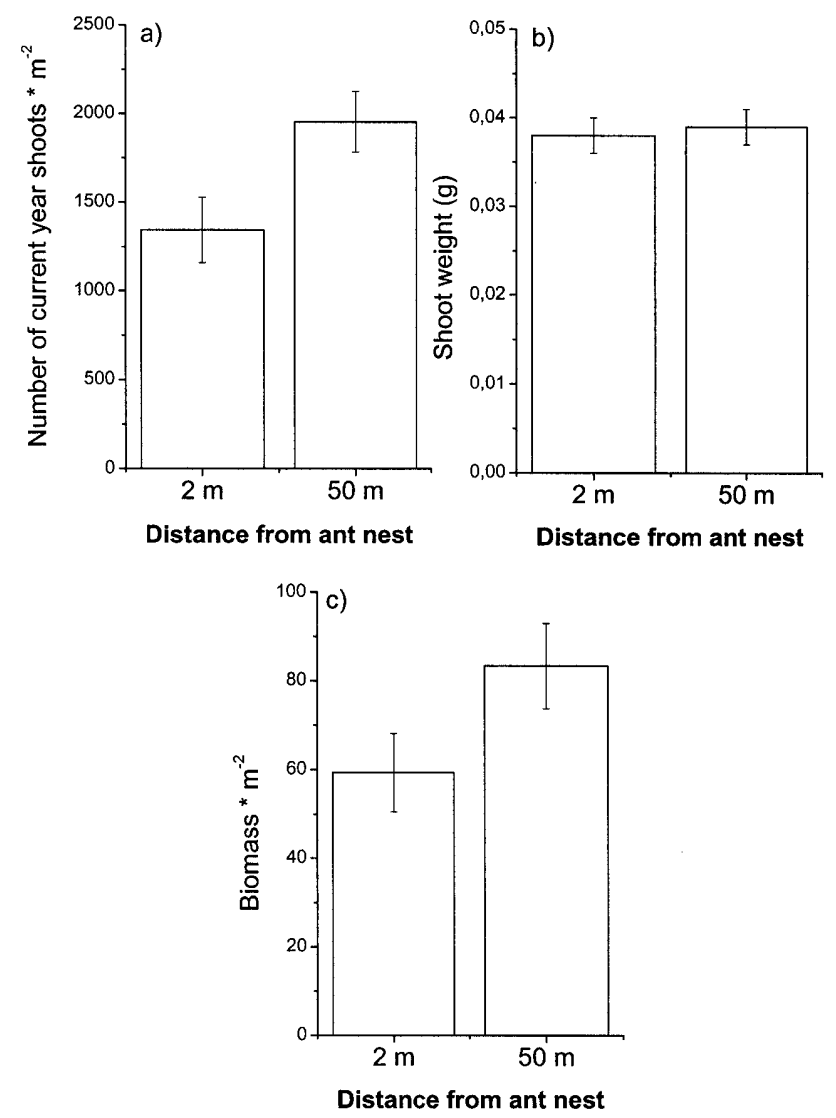

Fig. 1. The bilberry's vegetative production measured as a) the mean number of activated current year shoots $/ \mathrm{m}^{2}, \mathrm{~b}$ ) the mean weight of bilberry current year shoot, and c) the mean biomass of current year shoots $/ \mathrm{m}^{2}$, in positions close to $(2 \mathrm{~m})$ and far away $(50 \mathrm{~m})$ from ant nests, $\pm 1 \mathrm{SE}$ is indicated by vertical lines. Ants had no indirect effect on the bilberry's vegetative production. 

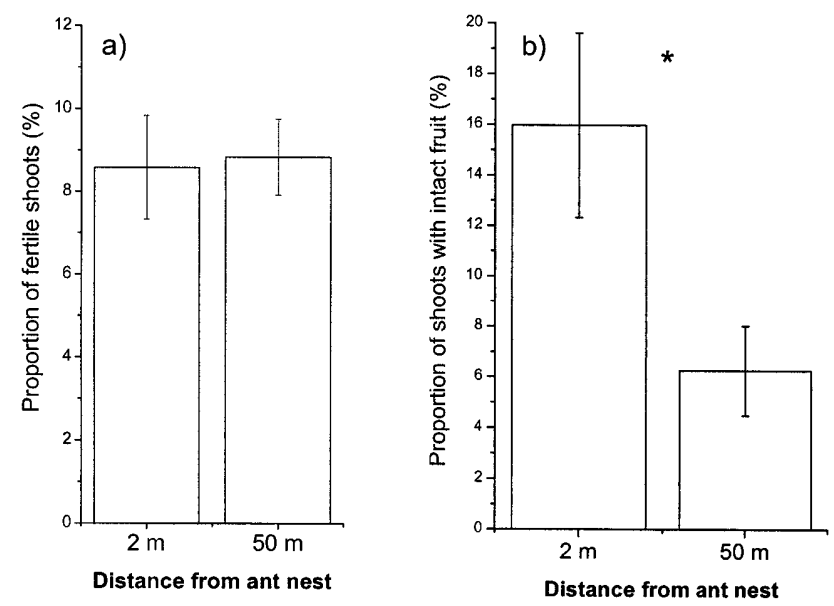

Fig. 2. Sexual production of bilberry measured as a) investment in sexual reproduction, i.e. the mean proportion of the bilberry's shoots that were fertile, and b) reproductive success measured as the mean proportion of fertile shoots with intact fruit, in sampling positions close to $(2 \mathrm{~m})$ and far away $(50 \mathrm{~m})$ from ant nests, $\pm 1 \mathrm{SE}$ is indicated by vertical lines. Ants did not significantly affect bilberry's investment in sexual reproduction but had a significant indirect effect on reproductive success $(\mathrm{p}<$ $0.05)$.

berry's current year shoots $\left(\mathrm{z}=-0.77, \mathrm{p}=0.2206, \mathrm{n}_{1}\right.$ and $\left.\mathrm{n}_{2}=24\right)$ and, the biomass of current year shoots $/ \mathrm{m}^{2}(\mathrm{z}=$ $0.55, \mathrm{p}=0.2912, \mathrm{n}_{1}=16$ and $\mathrm{n}_{2}=24$; Fig. 1 ).

The bilberry's reproductive investment, i.e., proportion of fertile shoots, was not significantly higher in positions close to compared to positions far away from the ant nests (Fig. $2 \mathrm{a} ; \mathrm{z}=0.02, \mathrm{p}=0.4920, \mathrm{n}_{1}$ and $\mathrm{n}_{2}=24$ ). However, reproductive success, i.e., the proportion of the fertile shoots with intact berries was significantly higher close to compared to far away from the nests (Fig. $2 \mathrm{~b} ; \mathrm{z}=2.13, \mathrm{p}$ $=0.0166, \mathrm{n}_{1}$ and $\mathrm{n}_{2}=24$ ).

Bark damage to bilberry, proportion of leaf area removed from bilberry shoots, and damage to the bilberry's reproductive parts were significantly lower close to compared to far away from the nests $(\mathrm{z}=2,56, \mathrm{p}=$ $0.0052, \mathrm{n}_{1}$ and $\mathrm{n}_{2}=24 ; \mathrm{z}=1.85, \mathrm{p}=0.0322, \mathrm{n}_{1}$ and $\mathrm{n}_{2}=$ $24 ; \mathrm{z}=2.56, \mathrm{p}=0.0052, \mathrm{n}_{1}$ and $\mathrm{n}_{2}=20$; respectively, Fig. $3)$.

\section{DISCUSSION}

My analysis suggests that distance to $F$. aquilonia nests, and thus predation pressure from ants, can significantly affect herbivore damage to bilberry and its reproductive success, thus supporting a top-down effect (c.f. Hairston et al., 1960) by the ants. However, since the vegetative production of the bilberry was not affected by ant workers, the bilberry seems to be able to compensate for losses caused by insect herbivores. Therefore, resource availability to the bilberry may also be important (c.f. White, 1978).

The results were in total agreement with the hypothesis that ants would reduce the level of damages inflicted by herbivores foraging on bilberry. Predation from ants most probably reduced the abundance of herbivores and there-
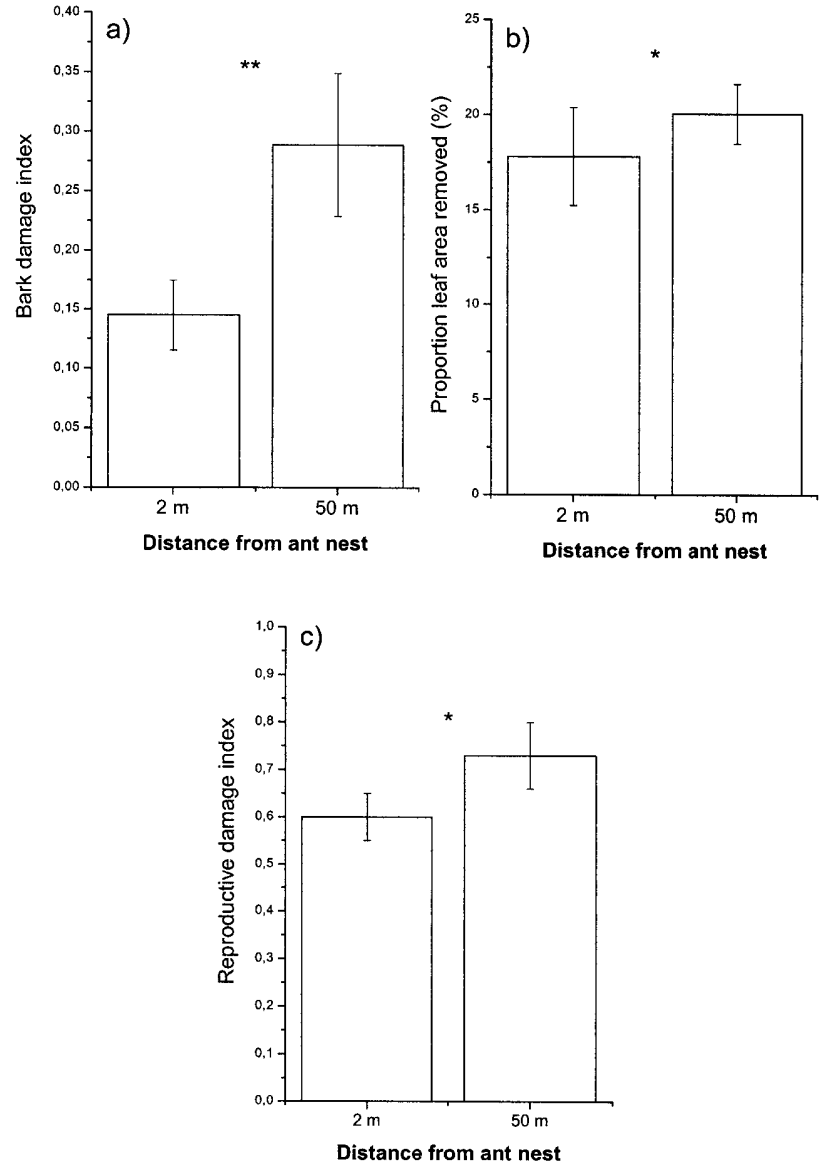

Fig. 3. Indirect effects of ants on herbivore damage to the bilberry measured as a) bark damage index, b) proportion of leaf area removed on current year shoots, and c) reproductive damage index, in positions close to $(2 \mathrm{~m})$ and far away $(50 \mathrm{~m})$ from ant nests, $\pm 1 \mathrm{SE}$ is indicated by vertical lines. For details on measurements of herbivore damage see methods. Ants significantly reduced bark damages $(\mathrm{p}<0.01)$, proportion of leaf area removed $(\mathrm{p}<0.05)$ and reproductive damage $(\mathrm{p}<0.05)$.

fore also the level of inflicted damages. This is in agreement with earlier studies (Skinner \& Whittaker, 1981; Risch \& Carroll, 1982; Fowler \& MacGarvin, 1985; Perfecto \& Sediles, 1992; Mahdi \& Whittaker, 1993).

The expected positive effect on the bilberry's vegetative production predicted by the top-down hypothesis was not detected. Bilberry has a more rapid growth, greater photosynthetic rate, and a higher storage of carbohydrate reserves below ground than other evergreen shrubs (Chapin, 1980; Sjörs, 1989), and its ability of to recover from a defoliation event is also good due to high numbers of dormant buds (Tolvanen \& Laine, 1997). The fact that bilberry is clonal could facilitate the re-establishment of leaves in injured shoots (Schmid et al., 1988; Sjörs, 1989). Furthermore, a lack of plant response in vegetative parts and reproductive investment is not uncommon in trophic interaction studies (Schmitz et al., 2000). They argued that plant damage from herbivores is a more shortterm response while the effect on the plant's biomass may not be directly influenced by immediate tissue damage, 
due to the fact that plants can make compensatory adjustments in biomass production over a long period.

With a lower level of herbivore damages in localities close to aquilonia nests, bilberry might be able to use additional resources for sexual reproduction and have more fertile shoots. My analysis revealed no evidence of this since the bilberry's reproductive investment did not differ close to compared to far away from the nests. Even though the leaves of the current year shoots can contribute to the ramet's own need for carbohydrates, and herbivores potentially could affect this, the investment in reproduction are largely dependent on resource levels the previous year (Tolvanen \& Laine, 1997). Ants, on the other hand, did affect the reproductive success of the bilberry since fertile shoots were significantly more successful in keeping their fruits intact close to compared to far away from ant nests. It seems that the $F$. aquilonia workers are capable of finding the frugivorous herbivores, preying on them and thereby reducing the level of damage on flowers and fruit. As a result, bilberry growing close to aquilonia nests (where worker density is high) will have a higher reproductive success.

The relative top-down effect in the food web has to be evaluated with regard to the temporal aspect. Both the vegetative and sexual efforts of the bilberry this season are of course also influenced by previous years. This study did not include measurements of herbivore density, but earlier studies have shown a close positive relationship between the levels of herbivory (measured with the same methods as in this study) and the density of herbivore larva (Atlegrim, 1989, 1991; Atlegrim \& Sjöberg, 1996). The damage levels found in the current study indicate, in comparison to earlier studies (Atlegrim, 1989, 1991; Atlegrim \& Sjöberg, 1996), that the density of insect larvae was low. If so, my data probably represent a conservative estimate of the indirect effects of ant predation compared to a long-term average because we might expect that if there was a higher larvae density, damages to the bilberry would probably diverge more between areas close to aquilonia nests and those areas farther away.

Due to the fact that this study was performed as an observational experiment, it is not possible to exclude that the observed pattern in the bilberry's response to herbivory also could be due to other reasons than an indirect effect of ant predation. One aspect that has been discussed concerning ant's potential as a top-down force is the fertilisation effect they have. Through a continuous transport of litter and prey items into the nest, the ants concentrate soil nutrients in and around the mounds (Laakso \& Setälä, 1997) within a radius of $1-1.5 \mathrm{~m}$ around the nest (Beattie \& Culver, 1977). Higher nutrient availability has, however, been refuted several times as the explanation of the "green islands" of mountain birch surrounding ant nest mounds in the Scandinavian highlands, in favour of the predatory effect from $F$. aquilonia workers on folivorous herbivores (Karhu, 1998; Karhu \& Neovonen, 1998). Further considering that my analysis revealed that bilberry's vegetative production did not differ between localities close to and far away from the ant nests, it appears that a fertilisation effect is unlikely.

However, ants do not localise their nests at random. It is therefore possible that microhabitat conditions differed between localities close to and far away from the aquilonia nests, and also contributed to the observed patterns. Overall though, my results suggest that bilberry indirectly was affected by ant predation on herbivorous larvae, and in particular the reproductive success of the bilberry was affected.

ACKNOWLEDGEMENTS. I thank M. Högberg for field and laboratory work. Suggestions from K. Danell greatly improved the manuscript and I thank J.P. Ball for correcting the English.

\section{REFERENCES}

Aho T., Kuitunen M., Suhonen J., Jäntti A. \& Hakkari T. 1997: Behavioural responses of Eurasian treekreepers, Certhia familliaris, to competition with ants. Anim. Beh. 54: 1283-1290.

Atlegrim O. 1989: Exclusion of birds from bilberry stands: Impact on insect larval density and damage to the bilberry. Oecologia 79: 136-139.

ATLEGRIM O. 1991: Interactions Between the Bilberry (Vaccinium myrtillus) and a Guild of Insect Larvae in a Boreal Forest. Ph.D Thesis. Department of Ecology, Swedish University of Agricultural Sciences, Umeå, 26 pp.

Atlegrim O. \& SJöBerg K. 1996: Effects of clear-cutting and single-tree selection harvests on herbivorous insect larvae feeding on bilberry (Vaccinium myrtillus) in uneven-aged boreal Picea abies forests. Forest Ecol. Manag. 87: 139-148.

BeAttie A.J. \& Culver D.C. 1977: Effects of the mound nests of the ant, Formica obscuripes, on the surrounding vegetation. Am. Midl. Nat. 97: 390-399.

CHAPIN III F.S. 1980: Nutrient allocation and responses to defoliation in tundra plants. Arctic Alpine Res. 12: 553-563.

Donisthorpe H.J.K. 1927: British Ants. Routledge \& Sons, London, xxiii +244 pp, 16 plates, 55 text figs.

Douwes P. 1995: Sveriges myror [The Swedish ants]. Entomol. Tidskr. 116: 83-99 [in Swedish, English abstr.].

Fowler S.V. \& MacGarvin M. 1985: The impact of hairy wood ants, Formica lugubris, on the guild structure of herbivorous insects on birch, Betula pubescens. J. Anim. Ecol. 54: 847-855.

Hairston N.G., Smith F.E. \& Slobodkin L.B. 1960: Community structure, population control, and competition. Am. Nat. 44: 421-425.

Havas P. \& Kubin E. 1983: Structure, growth and organic content in the vegetation cover of an old spruce forest in northern Finland. Ann. Bot. Fenn. 20: 115-149.

Hölldobler B. \& Wilson E.O. 1990: The Ants. Harvard University Press, Cambridge, MA, pp. 1-3, 216-217.

Hunter M.D. \& Price P.W. 1992: Playing chutes and ladders: Heterogeneity and the relative roles of bottom-up and topdown forces in natural communities. Ecology 73: 724-732.

Kalliola R. 1973: Suomen Kasvimaantiede. [Finnish Plant Growing Seasons.] Werner Söderström, Poorvoo, Helsinki, 308 pp. (in Finnish).

KARHU K.J. 1998: Effects of ant exclusion during outbreaks of a defoliator and a sap-sucker on birch. Ecol. Entomol. 23: 185-194.

Karhu K.J. \& Neuvonen S. 1998: Wood ants and a geometrid defoliator of birch: predation outweighs beneficial effects through the host plant. Oecologia 113: 509-516. 
LaAkso J. \& SetÄLÄ H. 1997: Nest mounds of red wood ants (Formica aquilonia): hot spots for litter-dwelling earthworms. Oecologia 111: 565-569.

LAAKSO J. \& SetÄLÄ H. 1998: Composition and trophic structure of detrital food web in ant nest mounds of Formica aquilonia and in the surrounding forest soil. Oikos 81: 266-278.

LAINE K.L. \& NiEMELÄ P. 1980: The influence of wood ants on the survival of mountain birches during an Oporinia autumnata (Lep., Geometridae) outbreak. Oecologia 47: 39-42.

LAWTON J.H. 2000: Community ecology in a changing world. In Kinne O. (ed.): Excellence in Ecology. Vol. 11. Ecological Institute, Oldendorf/Luhe, Germany, $227 \mathrm{pp}$.

MAHDI T. \& WhitTAKer J.B. 1993: Do birch trees (Betula pendula) grow better if foraged by wood ants? J. Anim. Ecol. 62: 101-116.

Mossberg B., Stenberg L. \& Ericsson S. 1992: Den Nordiska Floran. Whalström \& Widstrand, Stockholm, 696 pp. (in Swedish).

OINONEN E.A. 1956: On the ants of the rocks and their contribution to the afforestation of rocks in southern Finland. Acta Entomol. Fenn. 12: 1-212 (in Finnish, English abstr.).

OINONEN E. 1958: [Signs of forest fires and possibilities to characterize prefire forests]. Metsätaloudellinen Aikakauselehti 2: 1-4 (in Finnish).

Perfecto I. \& Sediles A. 1992: Vegetational diversity, ants (Hymenoptera, Formicidae), and herbivorous pests in a neotropical agroecosystem. Envir. Entomol. 21: 61-67.

Persson L. 1999: Trophic cascades: abiding heterogeneity and the trophic level concept at the end of the road. Oikos $\mathbf{8 5}$ : 385-397.

Polis G.A. 1999: Why are parts of the world green? Multiple factors control productivity and the distribution of biomass. Oikos 86: 3-15.

Polis G.A. \& Strong D.R. 1996: Food web complexity and community dynamics. Am. Nat. 147: 813-846.

POWER M.E. 1992: Top-down and bottom-up forces in food webs: do plants have primacy? Ecology 73: 733-746.

PuntTila P. 1996: Succession, forest fragmentation and the distribution of wood ants. Oikos 75: 291-298.

RisCH S.J. \& CARROLL C.R. 1982: Effect of a keystone predaceous ant, Solenopsis geminata, on Arthropods in a tropical agroecosystem. Ecology 63: 1979-1983.
RoSENGREN R. 1981: Röda skogsmyran och miljön. [The red wood ant and the environment.] Finl. Natur 5-6: 131-135 (in Swedish).

Savolainen R., VepsäläInen K. \& Wuorenrinne H. 1989: Ant assemblages in the taiga biome: testing the role of territorial wood ants. Oecologia 81: 481-486.

Schmid B., Puttick G.M., Burgess K.H. \& Bazzaz F.A 1988: Clonal integration and effects of simulated herbivory in oldfield perennials. Oecologia 75: 465-471.

Schmitz O.J., Hambäck P.A. \& BecKerman A.P. 2000: Trophic cascades in terrestrial systems: A review of the effects of carnivore removals on plants. Am. Nat. 155: 141-153.

SCHOENER T.W. \& SPILLER D.A. 1996: Devastation of prey diversity by experimentally introduced predators in the field. Nature 381: 691-694.

Schoener T.W. \& Spiller D.A. 1999: Indirect effects in an experimentally staged invasion by a major predator. Am. Nat. 153: 347-358.

SiEgel S. 1956: Nonparametric Statistics for the Behavioural Sciences. McGraw-Hill, New York, 312 pp.

Sih A., Crowley P., McPeek M., Petranka J. \& Strohmeier K. 1985: Predation, competition and prey communities: A review of field experiments. Annu. Rev. Ecol. Syst. 16: 269-311.

SJöRS H. 1989: Blåbär, Vaccinium myrtillus - ett växtporträtt. [The bilberry, Vaccinium myrtillus - a plant portrait.] Sv. Bot. Tidskr. 83: 411-428 (in Swedish).

SkinNer G.J. \& WhitTAKer J.B. 1981: An experimental investigation of inter-relationships between the wood-ant (Formica rufa) and some tree-canopy herbivores. J. Anim. Ecol. 50: 313-326.

SPILler D.A. \& SChoener T.W. 1998: Lizards reduce spider species richness by excluding rare species. Ecology 79: 503-516.

Strong D.R. 1992: Are trophic cascades all wet? Differentiation and donor-control in speciose ecosystems. Ecology 73: $747-754$.

Tolvanen A. \& Laine K. 1997: Effects of reproduction and artificial herbivory on vegetative growth and resource levels in deciduous and evergreen dwarf shrubs. Can. J. Bot. 75: 656-666.

White T.C.R. 1978: The importance of a relative shortage of food in animal ecology. Oecologia 33: 71-86.

Received April 27, 2004; revised January 3, 2005; accepted January 10, 2005 